\title{
Türkiye'de Ruhsal Hastalığı Olan Bireylere Yönelik Kurum Bakım Hizmetleri ve Bu Hizmetlerde Sosyal Hizmet Uygulamaları*
}

\author{
Residential care services for the people with mental illness in Turkey and \\ social work practices in this services
}

\author{
Ayten KAYA KILIÇ ${ }^{1 \text { a }}$ \\ Sema YILMAZ ${ }^{2}$
}

\begin{abstract}
${ }^{1}$ Muğla Sıtkı Koçman Üniversitesi, Seydikemer Uygulamalı Bilimler Yüksekokulu, Muğla. ayteney@hotmail.com
${ }^{2}$ Selçuk Üniversitesi, Sağlık Bilimleri Fakültesi, Konya. syilmaz33@gmail.com

a Yazışılan yazar/Corresponding author
\end{abstract}

\begin{abstract}
Özet
Ruhsal hastalı̆̆ı olan bireylere yönelik toplum tarafindan sağlanan hizmetler zamana ve toplumların bakıs açısına göre değişikliğe uğramıştır. Ruhsal hastaları kurumlara kapatma gelene ği 1950'li yillardan sonra yerini toplum temelli hizmetlere bırakmıştır. Ancak toplumda tedavi edilemeyen, gidecek yeri olmayan kimsesiz ruhsal hastalığı olan bireylere yönelik kurum bakım hizmetleri 1990'lı yıllardan sonra tekrar önem kazanmaya başlamıştır. Türkiye'de kurum bakım hizmetlerine yönelik 2000'li yıllardan sonra çıkarılan yasalar çerçevesinde özel yatılı bakım merkezleri desteklenmiş ve yayginlaştırılmıştır. Bu doğrultuda, özel yatılı bakım merkezlerinde sosyal hizmet uzmanlar da istihdam edilmeye başlamıştır. Bu çalışma, Türkiye'de kurum bakım hizmetlerinin gelişimi ve yasal düzenlemeleri, kurumlarda verilen hizmetler ile merkezdeki sosyal hizmet mesleğinin uygulama alanlarma yönelik düzenlenen bilgilerin literatüre ve alanda çalışan sosyal hizmet meslek elamanlarma katkı sunması amacryla hazırlanmıştır.
\end{abstract}

Anahtar kelimeler: Ruhsal hastalik, Bakım merkezi, Sosyal hizmet uzmanı

JEL kodlart: I12, I18

\begin{abstract}
The services provided by society towards individuals with mental illness have changed according to time and from the point of view of the societies. The tradition of closing mental patients to institutions has left its place to community-based services after the 1950s. However, institutional care services for individuals who can not be treated in society, have no place to go, orphaned mental illness have begun to gain importance after years of 1990s. Private residential care centers have been supported and disseminated after with the legislation enacted in the 2000s for the institutional care services in Turkey. In this direction, social workers have begun to be employed in private residential care centers. This study, was prepared in order to contribute for the literature and social work profession information about development and regulation of institutional care services in Turkey, services at institutions.
\end{abstract}

Keywords: Mental illness, Nursing home, Social worker

JEL codes: 112, I18

\footnotetext{
* Bu Makale, “Bakım Merkezinde ve Ailesi Yanında Yaşayan Ağır Ruhsal Hastalığı Olan Bireylerin Sosyal Destek Algısı İle Yaşam Kalitesinin İncelenmesi” isimli doktora tezinden üretilmiştir.
} 


\section{GİRIŞ}

Dünya'da engelli nüfusunun oranının \%15 civarında olduğu ve bu oranın \%12-15'inin de ruhsal hastalıklardan kaynaklanan engelliler olduğu tahmin edilmektedir (Thornicroft ve Tansella, 2003; DSÖ raporu, 2011; Camkurt, 2013: 79; İnan vd., 2013). Ruhsal hastalık sonucunda oluşan engellilik, Amerika Birleşik Devletleri'nde (ABD) her yıl 4.8 milyon civarında yetişkini etkilediği (Carpenter, 2002) ve son yirmi yılda bakım merkezlerinde kalan ağır ruhsal hastalığı olan kişilerin sayısında artış olduğu bildirilmektedir (Mechanic ve McAlpine, 2000; Donovan, 2013; Rahman vd., 2013; Leedahl, 2015: 172).

Türkiye'de engelli oranlarıyla ilgili Devlet İstatistik Enstitüsü (DİE) tarafından 2002 yılında yapılan Türkiye Engelliler Araştırması'na göre; engelli nüfusun toplam nüfus içindeki oranı \%12,29'dur. Ayrıca, TUIKK 2010 yılı verilerinde, Ulusal Özürlüler Veri Tabanına kayıtlı engellilerin \%3,9'unun ruhsal ve duygusal engelliler olduğu bildirilmektedir (www.tuik.gov.tr / Erişim tarihi 10 Nisan 2017).

Ruhsal hastalıklar, şizofreni, bipolar bozukluk ya da depresyon gibi tüm ruhsal bozuklukları ifade eden, davranışlarda, ruh halinde ve düşüncelerde olağandışı değişikliklerin sürekli olması ile karakterize olan hastalıklardır (Reeves ve ark 2011, Street ve ark 2013: 389). Ruhsal hastalıkların bireyin düşünce ve davranışsal yapısında yarattığı olumsuz etkiler sonucunda, bireylerin bilişsel fonksiyonları ve sosyal işlevsellikleri bozulmaktadır (Liberman 2011; Akpınar ve Kelleci, 2008: 180-190). Kronik ruhsal hastaların \%10-15'inin bakım gerektiren hastalar olduğu (Yanık, 2007), birçok araştırmada da bu durumun, bireyler, aileler ve toplum üzerinde olumsuz sosyal ve ekonomik sonuçlara yol açtı̆̆ 1 bildirilmektedir (Caldas vd., 2011; Saruç ve Kaya Kılıç, 2015: 53-71; Aslantürk, 2016: 259; Bademli vd., 2016).

Yirminci yüzyılın ikinci yarısından sonra ruhsal hastaların tedavilerinin toplum içinde yapılmasını hedefleyen politikalar, Avrupa'da ve Amerika'da olmak üzere dünyanın birçok yerinde uygulama alanı bulmuştur. Benimsenen bu politikalar çerçevesinde toplumlar; ailesiyle birlikte yaşayacak durumdaki ruhsal hastalığı olan bireyler için destekleyici hizmetler üretmiş, uzun yıllar psikiyatri kliniğinde gözetim altında tutulan kimsesiz ve bakıma muhtaç kişiler içinde grup evleri, bakım merkezleri gibi yatılı bakım hizmetlerini geliştirmiş̧tir (Lehman vd., 1991: 35; Mares vd., 2002: 447). Türkiye' de bu dönüşüm 2000'li yıllardan sonra çıkarılan yasal düzenlemelerle sağlanmış ve bu doğrultuda özel yatılı bakım merkezleri desteklenmiştir.

Türkiye'de özel yatılı bakım hizmetlerinin kısa bir geçmişi olması nedeni ile yatılı bakım merkezleri, bu merkezlerde sunulan hizmetler ile bakım merkezindeki sosyal hizmet uygulamalarına dair çalışmalar sınırlıdır. Bu nedenle bu derleme makale, literatüre ve alanda çalışan sosyal hizmet meslek elamanlarına katkı sağlaması açısından önemlidir. Bu doğrultuda çalışmada, ruhsal hastalık ve ruhsal hastalık sonucunda oluşan bakıma muhtaçlık durumu, Dünya'da ve Türkiye'de ruhsal hastalara yönelik kurum bakım hizmetlerinin gelişimi, kurumlarda verilen hizmetler ile sosyal hizmet mesleğinin uygulamasına yönelik bilgiler düzenlenmiştir.

\section{RUHSAL HASTALIK, AĞIR RUHSAL ENGELLİ ve BAKIMA MUHTAÇLIK}

Antik Çağ'da ruhsal hastalıklar, bireyin sağlıklı olma halinden uzaklaşması, normalden farklı olma hali olarak düşünülmüştür. Akıl/ruhsal hastalığın tanımlanması ilk kez Hipokrat 
tarafından yapılmış ve ruhsal hastalığın beden sıvılarındaki dengesizlik nedeniyle oluştuğu belirtilmiştir. Daha sonra, Galen akıl/ruh hastalıklarının beyinden kaynaklandığını belirterek tıp tarihi açısından önemli bir adım atılmasını sağlamıştır (Çetin, 2005; Akın, 2014).

Çağlar boyunca değişime uğrayan ve farklı boyutlarda yeni tanımlar kazanan ruhsal hastalık, DSM IV'e göre şu şekilde tanımlanmaktadır: "Modern psikiyatrik sinıflamada hastalık veya bozuklukla bireyde sıkıntıya ve/veya yeti yitimine yol açan psiko-sosyal veya biyolojik bir işlev bozukluğudur." (Turkçapar ve Göka, 1995: 179). Endüstrileşme, hızlı nüfus artışı, sosyal ve ekonomik yetersizlikler gibi çevresel ve sosyal etmenler kronik hastalıkları ve neden olduğu engelli oranlarını artırmaktadır (Genç ve Barış, 2015). Engelliler Hakkında Kanun'a (5378 sayılı) göre engelli: “Fiziksel, zihinsel, ruhsal ve duyusal yetilerinde çeşitli düzeyde kayıplarından dolayı topluma diğer bireyler ile birlikte eşit koşullarda tam ve etkin katılımını kısıtlayan tutum ve çevre koşullarından etkilenen birey" (Madde 3/c) olarak belirtilmektedir.

Ruhsal hastalık sonucunda oluşan engellilik, kişilerin yaşam koşullarında, aile ortamlarında, sosyal iletişimlerinde, ekonomik koşullarında ve güvenlikleri gibi birçok alanda gerilemelerine neden olmakta (Solanki vd., 2008: 181; Taylor vd., 2009) ve bireylerde farkl1 derecelerde ve boyutlarda görülmektedir (Yıldız, 2009: 151). Kimi hasta düzenli tedavi ile toplumsal hayata uyum gösterebilirken kimi hastada oluşan bilişsel yıkım geri dönülmez bir biçimde hastayı kendi kendine bakamaz duruma getirebilmektedir. Özürlülere Verilecek Sağlık Kurulu Raporları Hakkında Yönetmelik'te ruhsal hastalığı olan bir kişinin ağır engelli olarak kabul edilebilmesi için, tüm vücut işlev kaybı oranının yüzde 50'den yukarıda olması, öz bakımını karşılamada yetersiz olması, tek başına hareket edememesi, çevresiyle iletişim kurmada sıkıntı yaşaması ve aynı zamanda da tüm bu hayati becerileri başka kişilerin desteği olmadan yapamayacağına tıbben karar verilmesi gerektiği belirtilmektedir (Çabalar vd., 2011: 142-146).

$\mathrm{Bu}$ tanımlarda görüldüğü gibi, ağır ruhsal engellilik sonucunda birey başka bir kişinin yardımına muhtaç hale gelebilmektedir. Bakıma muhtaçlık, kişilerin bazı hareketleri, duyuları veya işlevlerinin kısıtlanması nedeniyle en temel ihtiyaçlarını (yemek yapma ya da yeme, giyinme, beden temizliği, alışveriş vb.) dahi karşılayamaması, hayatını tek başına devam ettirememesi, ancak bir başkasının desteklemesi ile günlük hayatına devam edebilmesi durumudur (Danış ve Genç, 2011; Şişman, 2011: 169).

\section{RUHSAL HASTALARA YÖNELIKK KURUM BAKIM HİZMETLERINIIN GELISŞIMİ}

Dünyanın var olduğu ilk günden bu yana, ruhsal hastalığa ve hastalara yönelik yaklaşımlar tüm toplumlarda ve dönemlerde değişiklik göstermiştir. İlk Çağ'da ruhsal hastalığın nedeninin doğaüstü güçlerin, kötü ruhların etkisi ile olduğunu (Yüksel, 2001; Köknel, 2000; Çetin, 2005) düşünen toplumlar ruhsal hastaları ötekileştirmiş, onlardan uzak durmuş ve bakımlarını ailelerinin sorumluluğuna bırakmıştır. Orta Çağ boyunca etkisini sürdüren bu düşünce ruhsal hastaların gözden uzakta olmaları için hastanelere, düşkünler evine ya da yerel hapishanelere kapatmaya zorlamıştır (Zastrow, 2014). Foucault (1993), kapatmanın anlaminı "Gruba kendi açısından türdeş olmayan veya zararlı olan unsurları yok etme olană̆ı veren karanlık bir amacın içinde tükenmektedir" olarak ifade etmiştir. Kapatma uygulaması Avrupa'nın tümünde uzun süre devam etmiştir. On üçüncü yüzyllda Londra'da kurulan "Bedlam" (Bethlehem), Avrupa'nın ruhsal hastalıklar konusunda uzmanlaşan ilk ve en eski 
kurumu olarak, aile ve arkadaş desteğinden yoksun, tehlikeli, yoksul ve marjinal gruplara hizmet vermiş ve ruhsal hastalar için sığınak ve tapınak işlevi görmüştür (Salter ve Turner, 2008, Özbaş ve Buzlu, 2011).

Avrupa'da yaşanan bilimsel gelişmeler, ruhsal hastalara yönelik yaklaşımları değiştirmeye başlamış, on yedinci yüzyılda hastalar hakkında kararları din adamları yerine hekimler vermeye başlamıştır. On sekizinci yüzyılda Fransız ruh hekimi olan Pinel tarafından başlatılan "İnsancıl Akım" ile ruhsal hastaların tedavilerinin hastanelerde ve bakım evlerinde yapılmalarını öngören düşünce, Avrupa'da ve Amerika'da yaygınlaşmaya başlamıştır (Öztürk, 1997). ABD'de 1751 yılında açılan “Pensilvanya Akıl Hastanesi” ruhsal hastalara yönelik tedavilerin verildiği ve aynı zamanda bakımlarının da yapıldığı ilk genel hastanedir (Özbaş ve Buzlu, 2011). On dokuzuncu yüzyılda aileler ve yerel topluluklar dışındaki kurumlarda ruhsal hastaların tedavisinin yapılmasının doğru bir çözüm olduğu düşünülmüş "Kurumsallaşma" yönünde toplumsal bir süreç başlamıştır (Yohanna, 2013: 886). ABD' de 1861 yılında toplam 40 akıl hastanesi (tımarhane) olması Amerika'daki ruhsal hastalara uygulanan kurumsallaştırılmayı göstermesi açısından önemlidir (Çetin, 2005).

Dünya' da ruhsal hastalara sağlanan bakım hizmetleri üç döneme ayrılmaktadır:

Birinci dönem: Ruhsal hastalara uzun dönem hastane ya da düşkünler evi gibi kurumlarda sağlanan tedavi ve bakım hizmetleri (Institutionalization):

On sekizinci yüzyıla kadar ruhsal hastalığı olan kişilerin bakımları çoğunlukla aileleri ve toplumun sorumluluğundaydı. Ancak bu durum sanayi devrimi ile değişmeye başlamış ve on dokuzuncu yüzyılda daha da gelişecek şekilde, kurumsal bir yaklaşım yerini almaya başlamıştır (Gilburt vd., 2014Ü; Genç ve Barış, 2015). On altıncı yüzyılın ilk dönemlerinde Ausburg'da kurulan düşkünler evi ile 18. yüzyılda Rahibe Theresia tarafından kurulan düşkünler evi, bugün kullandığımız bakımevi kavramının temelini oluşturmaktadır (Soygür, 2000: 32-40). On dokuzuncu yüzyıl ile yirminci yüzyılın ortalarına kadar bu düşkünler evinin (Asylum) asıl amacı, ağır ruhsal hastaların bakımlarının yapılmasıydı (Chow ve Priebe, 2013).

İkinci dönem: Ruhsal hastaları psikiyatrik hastanelerden ya da kurumdan çıkararak toplum temelli sağlanan tedavi ve rehabilitasyon hizmetleri (Deinstitutionalization):

Yirminci yüzyılın ortalarına kadar, ruhsal hastalığı olan bireylerin hastanelerde uzun süreli yatışları önemli yer tutmuştur. Ruhsal hastaları düşkünler evine kapatan bu sistem ve düşünceler, 1950'li yıllarda değişmeye başlamıştır. Bu yeni düşünce ve akımlar sonucunda büyük çaptaki düşkünler evleri kapatılmış ya da hastanelerdeki psikiyatrik yatak sayıları azaltılmış ve ruhsal hastaların bakımlarının ve rehabilitasyonlarının toplum içinde yapılması hedeflenmiştir (Çetin, 2005; Priebe vd., 2005: 123). Bunda, insan hakları hareketi, tedavideki gelişmeler (antipsikotik ilaçların faydaları), toplumda alternatif bakım hizmetlerinin ve programlarının gelişimi, kurum bakım maliyetlerinin yüksek olması gibi nedenler etkili olmuştur (Shadish ve Bootzin, 1981; Chow ve Priebe, 2013). “Toplum Temelli Model" ağır ruhsal bozukluğu olan bireylerin uzun süre ya da tekrarlayan şekilde hastane yatışlarının önüne geçirilmesi, ailelerinin yanında desteklenmesinin gerekliliği üzerine odaklanmış, gündüz hizmet veren Toplum Ruh Sağlığı Merkezleri'nin kurulması amaçlanmıştır (Alataş vd., 2009: 25-29; Saruç ve Kaya Kılıç, 2015: 53-71). 
Üçüncü dönem: Toplumda bakılamayan hastaların yeniden kurum bakım altına alma. Kurum bakımında tedavi ve rehabilitasyon hizmetleri (Reinstitutionalization):

Yirminci yüzyılın son yıllarına gelindiğinde, toplum temelli model ile birlikte ruhsal hastalara yönelik kurum bakım hizmetleri tekrar etkin hale gelmeye başlamıştır. Bunda, ağır ruhsal hastaların sayısındaki ciddi artışlar, kadının ev içinde bakım veren eleman olmaktan uzaklaşması ve profesyonel iş kadınlığı rolünü üstlenerek geleneksel ailedeki sosyal desteğin kaybolması (Priebe vd., 2005: 123), Avrupa'da birçok ülkede ruhsal hastaların adli yatış oranındaki artışlar ile açıklanabilmektedir (Priebe vd., 2008: 570).

Ruhsal hastalığı olan bireylere sunulan hizmetlerin gelişme sürecinde, bakım merkezleri ruh sağlığı hizmetlerinin dağıtımında önemli bir ihtiyacı karşılamaktadır (Anderson vd., 2001). Herhangi bir kişinin yaşamının herhangi bir zaman diliminde bakım merkezine ihtiyaç duyma olasılığının \%25 olduğu tahmin edilmektedir (Soygür, 2000: 32-40). Goffman (1961), "Asylums" kitabında ruhsal hastaların bakımlarının yapıldığı hastaneleri bütüncül kurumlar olarak ele alıyor ve şu şekilde tanımlıyor: "Benzer durumu yaşayan bireylerin, belli bir zaman süresince dış dünyadan izole ve kapalı olarak yaşadığı, gözetim altında tutulduğu ve yönetildiği yaşam ya da çalışma alanlarıdır". Chow ve Priebe (2013), günümüzde modern anlamda kullanılan kurumsal bakımı, eski ve geleneksel kurum bakımına dayalı olan ancak toplum tarafından oluşturulan yeni hizmetler olarak tanımlıyor.

Kurum bakımı; aile yanında bakılması mümkün olmayan, kimsesiz, özel gereksinimli ve süreğen hastalığı nedeniyle bakıma ve korunmaya muhtaç bireylerin, barınma gibi temel ihtiyaçlarla birlikte psikolojik ve sosyal gereksinimlerinin yetişmiş kişilerce karşılandığı ve bunun ev ortamı yerine kurumda yapıldığı hizmetlerdir (Yaşlı ve Engelli Hizmetleri Genel Müdürlüğü 2010, Genç ve Barış, 2015).

\subsection{Türkiye' de Ruhsal Hastalara Yönelik Kurum Bakım Hizmetlerinin Gelişimi}

Selçuklu ve Osmanlı Devletinin ilk yıllarında kurulan, Bimarhaneler (akıl hastaneleri) ve Şifahaneler (hastane) ruhsal hastalarının sağaltımlarının yapıldığı kurumlardı. Selçuklu Dönemi'nde Amasya'da açılan Darüşşifa ruh hastalarının su ve müzik sesiyle tedavi edilmelerinin sağlandığı dünyadaki tek ve ilk merkez olma özelliği taşımaktadır (Çetin, 2005). Ayrica bu Şifahaneler Avrupa'daki gibi kentten uzak yerlerde değil aksine sosyal, kültürel ve dinsel etkileşimin yoğun olduğu kent merkezlerinde kurulmuştur. İlk olarak Fatih Sultan Mehmet zamanında ve daha sonra başka padişahlar tarafından akıl hastaneleri açılmış ve bu hastaneler ruhsal hastaların tedavilerinin ve bakımlarının yapıldığı başlıca kurumlar olarak yer almıştır (Öztürk, 1997; Yüksel, 2001).

Osmanlı Devleti döneminde engelliler, yaşlılar evinde koruma altına alınmışlar (1. Özürlüler Şurası) ve 19. yüzyıla kadar da sosyal hizmetler vakıflar tarafından sunulmuştur. On dokuzuncu yüzyılda Avrupa'da başlayan sosyal devlet anlayışı Osmanlıda etkisini göstermiş, toplumdaki ihtiyaç sahiplerinin koruyucusu olma rolünü devlet üstlenmeye başlamıştır. II. Abdülhamid tarafından yapılan sosyal refah çalışmaları ve bu anlamda tesis edilen kurumlar Osmanlı Dönemi'nde önemli bir yer edinmiştir (Akyol, 2013: 33-47). Bunlardan en önemlisi olan "Darülaceze" 1895 yılında kurulmuş, yoksul, engelli, yaşlı ve kimsesiz çocukların korunması ve bakımlarının yapılmasını yönünde kurum bakımı sağlayan sosyal hizmet kurumu olmuştur. 
Cumhuriyet dönemi, 1930 yılında yürürlüğe giren 1580 sayılı yasa ile ilk defa kamu kuruluşu olan belediyelere bakıma muhtaç kişilerin korunması, yaşlı evlerinin yapılması ve yönetilmesi yükümlülüğü getirilmiştir. Korunmaya muhtaç engellilerin, yaşlıların ve çocukların bakımlarının ve rehabilitasyonlarının yapılması yönünde Sosyal Hizmetler ve Çocuk Esirgeme Kurumu Genel Müdürlüğü 1983 yılında kurulmuştur (https://eyh.aile.gov.tr/ ET:19.04.2017). Sosyal Hizmetler (2828 say1lı) Kanunu'nun 4. maddesinde belirtilen genel esaslar kapsamında; bakıma muhtaç engellilerin tespit edilmesi, koruma altına alınması, bakımlarının sağlanması ile ilgili hizmetlerin yürütülmesi, bu hizmetler için gerekli sosyal hizmet kuruluşlarının kurulması ve işletilmesi ile ilgili görevleri yerine getirme görevi Sosyal Hizmetler ve Çocuk Esirgeme Kurumu (SHÇEK) Genel Müdürlüğü'ne verilmiştir. Bu doğrultuda, engelli bireylere hizmet vermeleri yönünde bakım hizmetlerine yönelik kurumlar açılmaya başlanmıştır.

\subsubsection{Türkiye'de Kamu ve Özel Yatılı Bakım Merkezleri ve Sunulan Hizmetler}

Türkiye'de engellilere yönelik kurum bakım hizmetleri ASPB, yerel yönetimler ve özel kuruluşlar tarafından verilmektedir. ASPB'ye bağlı resmi bakım merkezleri ile denetimine tabi olan özel bakım merkezlerinde her yaşta fiziksel, zihinsel ve ruhsal engelli bireylere yönelik gündüzlü ve yatılı bakım hizmetleri sunulmaktadır.

Tablo 1. Türkiye' de Resmi ve Özel Yatılı Bakım Merkez ve Yararlanan Engelli Sayıları

\begin{tabular}{|l|l|}
\hline \multicolumn{2}{|c|}{$\begin{array}{c}\text { ASPB ENGELLİ BAKIM HİZMETLERI DAİRE BAŞKANLIĞI } \\
\text { 2016 ARALIK GENEL VERİLERI }\end{array}$} \\
\hline RESMİ BAKIM MERKEZLERİ & 93 \\
\hline Yatılı Merkez Sayısı & 6 \\
\hline Gündüzlü Merkez Sayısı & 128 \\
\hline Umutevi & 227 \\
\hline Toplam Merkez Sayısı & 7458 \\
\hline Yatılı Kapasite & 6670 \\
\hline Yatılı Bakılan & 426 \\
\hline Yatılı Geçici Misafir & 411 \\
\hline Gündüzlü Bakılan & 7507 \\
\hline Toplam Bakılan Sayısı & 161 \\
\hline ÖZEL BAKIM MERKEZLERİ & 14.236 \\
\hline Özel Bakım Merkezlerinin Sayısı & 11.923 \\
\hline Özel Bakım Merkezlerinin Kapasitesi
\end{tabular}

(Kaynak: ASPB Yaşlı ve Engelli Hizmetleri Genel Müdürlüğü)

ASPB'den çalışma kapsamında 06.04.2017 tarihinde alınan resmi veriler incelendiğinde; Türkiye'de 2016 yılında ASPB'ye bağlı 227 resmi bakım merkezinde 7507 engelliye ve 161 özel yatılı bakım merkezinde ise 11.923 bakıma muhtaç engelli bireylere kurumsal bakım hizmetleri sunulduğu görülmektedir.

Türkiye'de engelli bireylerin kurum bakımı yerleştirilme işlemleri, ASPB İl/ilçe Müdürlüklerine ve özel yatılı bakım merkezlerindeki yönetim birimlerine başvuru ile gerçekleştirilmektedir. Engellinin kendisi, ailesi, mahkeme kararı var ise vasisi başvuru 
yapabilmekte, engellinin durumunu tespit eden tüm kurum ve kuruluşlarda engelli hakkında bildirimde bulunabilmektedir (Ulaş ve Uçku, 2012: 483).

Türkiye'de SHÇEK tarafından 2006 yılında yayınlanan Bakıma Muhtaç Özürlülere Yönelik Özel Bakım Merkezleri Yönetmeliği ile Türkiye' de ilk olarak engellilere yönelik yatılı bakım merkezini açma ve işletme yetkisini gerçek kişi ve özel hukuk tüzel kişilere verilmesi sağlanmıştır. Bu doğrultuda, ailesi yanında yaşaması mümkün olmayan ya da kimsesiz olan engelli bireyler koruma altına alınarak özel bakım merkezlerine yerleştirilmeleri yapılmaktadir.

Türkiye'de yatılı bakım merkezleri resmi ve özele ait kurumlar olmaları nedeni ile engelli yerleştirilmeleri de iki ayrı Yönetmelik çerçevesinde yapılmaktadır. ASPB'ye bağlı resmi bakım merkezlerine engellinin kabul işlemleri, 03.09.2010 tarihli ve 27691 sayılı Engellilerin Bakımı, Rehabilitasyonu ve Aile Danışmanlığı Hizmetlerine Dair Yönetmelik kapsamında, özel yatılı bakım merkezlerine engelli kabulünde, Bakıma Muhtaç Özürlülerin Tespiti ve Bakım Hizmeti Esaslarının Belirlenmesine İlişkin Yönetmelik kapsamında yapılmaktadır. Her iki yönetmeliğe göre, başvuru yapan ya da bildirimde bulunulan engellinin ailesinin yanında ya da yaşadığı yerde desteklenmesinin mümkün olmadığı takdirde uygun hizmet modelinin belirlenmesi gerektiği belirtilmektedir. Kişinin bakım ihtiyacı ile sosyal ve ekonomik durum tespiti yapılması yönünde sosyal inceleme raporu hazırlanmaktadır. Rapor doğrultusunda, yerleşeceği kurum ve ihtiyaç duyduğu bakım hizmetleri belirlenmektedir (https://eyh.aile.gov.tr/ ET:19.04.2017).

Resmi ya da özel yatılı bakım merkezine engelli bireyin kabulünde bazı yasal kriterlerin yerine getirilmesi gerekmektedir. Bu kriterlerden ilki, kişinin sağlık kurul raporuna göre ağır engelli olmasıdır. İkincisi, kişinin sosyo-ekonomik durumunun tespit edilmesidir. Bu iki kriter, engellinin resmi ya da özel bakım merkezinden yararlanması ve merkezin ücretinin ASPB tarafından ödenmesi noktasında yer alan en önemli unsurdur. Engellinin sosyo ekonomik durumunun incelenerek, 2828 sayılı Sosyal Hizmetler Kanunu ek 7. Maddesine göre; “Her ne ad altında olursa olsun her türlü gelirleri toplamı esas alınmak suretiyle; kendilerine ait veya bakmakla yükümlü olduğu birey sayısına göre kendilerine düşen ortalama aylık gelir tutarı bir aylık net asgarî ücret tutarının 2/3'ünden daha az olan bakıma muhtaç engellilerin, bakım merkezi tarafından verilen bakım hizmeti ücreti ASPB tarafından karşılanmaktadır.

Resmi ve özel bakım merkezlerinde, kişisel bakım ve psiko-sosyal destek hizmetleri verilmektedir. Kişisel bakım hizmetleri kapsamında; her türlü beden temizliği (Banyo, tuvalet, tırnaklar, saçlar, dişler, el, yüz, ayak, sakal tıraşı, burun ve kulak temizliği), yiyecek ve içecek ihtiyacının giderilmesi, elbiselerinin giydirilmesi, yaşadığı yerin temizlenmesi (Yatağın ve odanın temizlenmesi, çamaşırların yıkanması), tehlikelere karşı korunması ve gözetilmesi gibi birtakım hizmetleri kapsamaktadır. Bakım merkezlerinin tamamında tüm engelli gruplara belirlenen birincil bakım hizmetlerinin sağlanması yanında, merkezden merkeze ve merkezde kalanların engel gruplarına göre değişen şekillerde bağımsız yaşama, sosyal hayata ve kurum ortamina uyuma ilişkin sosyal rehabilitasyon hizmetleri de sunulmaktadır. Merkezlerde, müzik, resim, tiyatro, folklor gibi sanatsal ve kültürel faaliyetler; sportif çalışmalar; seramik ve el işi, bahçe çalışmaları gibi iş uğraş çalışmaları ile 
eğlenceler, kutlamalar, geziler gibi sosyal etkinlikler gerçekleştirilmektedir (Genç ve Barış 2015).

\section{BAKIM MERKEZINNDE RUHSAL HASTALIĞI OLAN BİREYLERE YÖNELİK SOSYAL HIZMET UYGULAMALARI}

Sosyal hizmet, insanların hayatlarında olumlu ilişkiler geliştirmelerini ve sürdürmelerini sağlayan (Mavili Aktaş, 2004), bireylere, ailelere ve topluluklara sosyal işlevselliklerini artırmaları ve uygun toplumsal koşulları yaratmaları için onlara yardım eden (Zastrow 2014), tüm bireylerin yaşam kalitesinin iyileştirilmesini ve yükseltilmesini (Şahin 2000), problemlerinin çözümlemeyi, ihtiyaçlarını karşılamayı amaçlayan bir meslektir (Turan 1999). Sosyal hizmet uzmanları, ruhsal hastalıkların yol açtığı çeşitli ekonomik veya sosyal sorunlarla baş etmede hastalara ve ailelere yardım etmekte ve desteklemektedirler (Özdemir 2000). Profesyonel bir meslek olarak psikiyatrik sosyal hizmetin, dezavantajlı durumdaki kişilere hizmet verilen kurum bakım hizmetlerinde uzun bir geçmişi vardır. Kurumlarda çalışan sosyal hizmet uzmanları görevleri gereği merkezde kalanların psikososyal ihtiyaçlarını ve haklarını savunmada yer almaktadırlar (Johnson ve Rhodes, 2007: 219; Vongxaıburana vd., 2011: 367). Ayrıca, ruhsal hastalıkların tedavisi dışında psikolojik sıkıntıların hafifletilmesi, güçlendirme sağlanması, bireylerin sorunlarını aşmada onlara cesaret verilmesi ve desteklenmesi gibi birçok istenilen görevleri yapmaktadır (Wakefield, 2013: 131).

Sosyal hizmetin ruh sağlığı alanındaki rolü psikiyatristler tarafından önceki dönemlerde önemsenmezken, duygusal sorunların organik sorunlardan daha öncelikli olduğunun fark edilmesi ile değişime uğramaya başlamıştır (Zastrow, 2014). Böylece günümüzde çok sayıda sosyal hizmet uzmanı ruhsal hastalığı olan bireylere hizmet verilen kuruluşlarda iş imkânı bulmaya başlamıştır (Carpenter, 2002). ABD'de ruh sağlığı hizmetlerinde çalışan sosyal hizmet uzmanlarının sayısı psikiyatrist ve klinik psikologlarından daha fazladır (Zastrow, 2014). Kurum bakımı sosyal hizmetlerin doğrudan ilgilendiği birincil çalışma alanlarıdır. Amerika'da 120 yataktan fazla olan bakım merkezlerinde tam zamanlı bir sosyal hizmet uzmanı görevlendirildiği ve en azından bir yıl sürecinde süpervizyon alması gerektiği belirtilmektedir (Bern-Klug ve Sabri, 2012: 5-20). ABD'de ülkenin birçok yerinde sosyal hizmet uzmanları, bakım merkezinde kalacak kişiyi ve aileleri ilk kabulde karşılayan, onlara merkeze girmede gerekli kriterleri tanitan öncellikli personel olarak belirtilmektedir (Lacey, 2005).

Türkiye'de 2016 yılında yayınlanan Engelli Bireylere Yönelik Özel Bakım Merkezleri Yönetmeliği'nde sosyal hizmet uzmanı/ sosyal çalışmacı meslek personeli arasında yer almış, ruhsal veya zihinsel engelli bireylere hizmet veren özel yatılı bakım merkez yönetimlerine psikolog ya da sosyal hizmet uzmanı/sosyal çalışmacı çalıştırma zorunluluğu getirilmiştir (Madde 33-2). İlgili Yönetmelik'te, bakım hizmetlerinde yer alan engelli bireyin bakımına yönelik psiko-sosyal destek hizmetleri ile engelli bireylere yönelik merkezde oluşabilecek fiziksel, cinsel, psikolojik, tıbbi ve ekonomik ihmal, istismarm tespiti ve bildirimin yapılmasının meslek personeli tanımlamasında yer alan sosyal hizmet uzmani/ sosyal çalışmacının görev, yetki ve sorumlulukları kapsamında olduğu belirtilmiştir (Madde 37-b).

Bakım merkezinde sosyal hizmetin altı görevi tanımlamıştır. Bunlar: 1. Ruhsal sağlıkla ilgili psikososyal değerlendirmelerin yapılması, 2. Bakım merkezinde kalanların ve ailelerin 
başetme becerilerinin geliştirmesinde psikososyal müdahalelerin yapılması, 3. Uzun süreli bakıma geçişte yardımcı olunması, 4. Bakım planlamasına katılımın sağlanması, 5. Bakım merkezi ekibi ile bakım planlaması konusunda işbirliği yapılması, 6. Bakım merkezinde kalanların bireysel karar alma sürecine katkı verilmesi (Vongxarburana vd., 2011: 367).

ABD Ulusal Sosyal Hizmet Uzmanları Derneği (NASW), uzun süreli bakım hizmetleri kapsamında, sosyal hizmet standartları için beş hedefi belirtmektedir.

- Sosyal hizmet uzmanları tarafından bakım merkezinde kalanlara ve ailelerine sosyal hizmetlerin doğrudan sağlanması,

- Toplum temelli sağlık, sosyal kaynaklar ve olanaklardan en üst düzeyde faydalanmaları ve kullanmaları konusunda bakım merkezinde kalanların ve ailelerinin desteklenmesi,

- Bakım merkezinde kalan bireyler, aileler ve personel arasında iletişimin güçlendirilmesi,

- Bakım merkezinde kalan bireylerin planlanan faaliyetlere ve uygulamalara en üst düzeyde katılımının sağlandığı, her bir bireyin bağımsız işlevselliğini ve yaşam kalitesini artıracak gerekli olan tedavi edici ortamın sağlandığı olanakların desteklenmesi,

- Kurumda kalanların ve kurum personelinin toplum içine katılımının yanı sıra, toplumdaki bireylerin kurum içindeki katılımını da teşvik ederek, kurum-toplum etkileşimini desteklemek, geniş çaptaki toplumsal kaynakları ile bağlantı kurulması, uzun dönem sosyal ve sağlık bakım kaynakları ile ilgili planlamalardaki ihtiyaçları değerlendirmede katılımın sağlanması (Bern-Klug vd., 2009: 36-44).

Bakım merkezindeki sosyal hizmet uygulamaları, fiziksel ve ruhsal engellilere, ailelerine yardım etmeye odaklanmaktadır. Sosyal hizmet uzmanları, fiziksel ve sosyal işlevselliğin geliştirilmesi ve korunmasına yardımcı olmakta ve yaşam kalitesinin en iyi şekilde geliştirilmesi konusunda hizmet sağlamaktadır (Bern Klug, 2009: 36-44). Bakım merkezinde kalanların yaşam kalitesi sosyal hizmet uzmanları ile ilişkilendirilmektedir (Raske, 2010: 336). Sosyal hizmetin değerleri, sosyal adalet, insanın değeri ve onuru, insan refahı, bütünlüğü ve yetkinliği içermektedir (Bern Klug, 2009: 36-44; Duyan, 2010: 96-107).

Ruh sağlığı alanında çalışan sosyal hizmet uzmanları, ruhsal hastaların sosyal hayatları ve duygusal yapıları arasında bir şekilde köprü kuran ve birbirinden farklı yönlerini kendi yararları için kullanmaları yönünde onları cesaretlendiren ve yönlendiren kişidir (Cameron ve McGowan, 2013: 21-32). Aynı zamanda, hastaların psikososyal sorunlarını çözmede hastanın ve ailenin hayatları üzerindeki güç ve kontrolleri (Oral ve Tuncay, 2012: 93) ile sosyal destekleri üzerine odaklanmakta ve artırılması yönünde çaba harcamaktadır (Daşbaş 2014). Psikiyatrik tedavinin devamında ve sonrasında ruhsal hastanın çevresine uyumunda gerekli olan sosyal destek ile ilgili çevrenin bilinçlenmesi, düzenlenmesi, aktif katılımının sağlanmasında sosyal hizmet uzmanları kilit rol oynamaktadır. Birey, aile ve toplumla çalışan sosyal hizmet uzmanları bireyin ihtiyaç duyduğu desteğin verilmesinde önemli meslek elemanlarıdır (Bahar ve Savaş, 2013: 83-90). 


\section{SONUÇ}

Ülkelerin sosyal ve demografik yapılarında ortaya çıkan değişiklikler, yaşlı nüfusunun artması, ruhsal hastalıklardaki artış gibi sosyal sorunları da artırmaktadır. Bu durum yeni çözüm önerilerinin geliştirilmesini zorunlu hale getirmektedir. Yeni hizmetlere olan ihtiyaç, ülkelerin ekonomileri üzerinde baskı yaratmakta, bu alanlara kaynak aktarımını zorunlu kılmakta ve yeni yasaların çıkarılmasına zemin hazırlamaktadır. Böylece, yasalar çerçevesinde yeni hizmet modelleri belirlenmekte ve yeni kurumlar açılmaktadır.

Dünya genelinde olduğu gibi Türkiye'de bakacak kimsesi olmayan, kendi imkânları ile toplum içinde yaşamlarını devam ettiremeyen bakıma muhtaç engelli sayısındaki artış bu alanda hizmet verecek bakım merkezlerinin açılmasında önemli unsuru teşkil etmiştir. Bakıma muhtaç ruhsal hastalığı olan bireylerin ihtiyaç duydukları bakım hizmetlerinden en üst düzeyde faydalanmalarını sağlamak sosyal refah devletinin başta gelen görevleri arasında yer almaktadır. Bu doğrultuda açılan ve işletilen bakım merkezleri ve bu merkezlerde verilen hizmetler önemli bir amaca hizmet etmektedir. Bakım merkezinde ruhsal hastalığı olan bireylerin fiziksel ve sosyal işlevselliğinin geliştirilmesinde ve korunmasında, psikososyal ihtiyaçların belirlenmesinde, sorunlarının çözümlenmesinde, yaşam kalitesinin yükseltilmesinde bakım hizmetleri kapsamında sosyal hizmet uygulamaları önemli yer tutmaktadır.

\section{KAYNAKÇA}

Akın, H. (2014). Antikçağ'dan Yeniçă̆g'a Delilik, Melankoli ve Cinlenme Avrupa'da Aykırı Olma Halleri Üzerine Tarihsel Bir İnceleme. Doktora Tezi, Hacettepe Üniversitesi, Ankara.

Akpınar, Ş. ve Kelleci, M. (2008). Şizofrenik Hastalara Uygulanan Sorun Çözme Becerilerini Geliştirme Programının Yaşam Kalitesine Etkisi. Klinik Psikiyatri, 11, 180-190.

Akyol, D. E. (2013). Sultan II. Abdülhamid Döneminde Sosyal Politika Uygulamaları. Sosyal Politika Çalışmaları, 33-47.

Alataş, G., Karaoğlan, A., Arslan, M. ve Yanık, M. (2009). Toplum Temelli Ruh Sağlı̆̆1 Modeli ve Türkiye' de Toplum Ruh Sağlığı Merkezleri Projesi. Nöropsikiyatri Arşivi, 46, 25-29.

Anderson R. L., Lyons, J. S., \& West, C. (2001). The Prediction of Mental Health Service Use in Residential Care. Community Ment Hlt J, 37(4), 313-322.

Aslantürk, H. (2016). Ruh Sağlığı Alanında Toplumsal Entegrasyon ve Sosyal Haklar. TJFMPC, 10(4), 259-270.

Bademli, K., Keser, İ., Lök, N., Kılıç, A. K., Güvendiren, H. ve Buldukoğlu K. (2016). Şizofreni Hastalarının ve Bakım Verenlerinin Eğitim Gereksinimlerinin Belirlenmesi. Anadolu Hemşirelik ve Sağlık Bilimleri Dergisi, 19(1),1-9.

Bahar, G. ve Savaş, H. A. (2013). Ruh Sağlığı Çalışmalarında Sosyal Hizmet Mesleğinin Rolü. New Syposium Journal, 51(2), 83-90. 
Bern-Klug, M., Kramer, W. O., Chan, G., Kane, R., Dorfman, L. T., \& Saunders, J. B. (2009). Characteristics of Nursing Home Social Services Directors: How Common is a Degree in Social Work?. J Am Med Dir Assoc, 10, 36-44.

Bern-Klug, M., \& Sabri, B. (2012). Nursing Home Social Services Directors and Elder Abuse Staff Training. J Gerontological Social Work, 55(1), 5-20.

Caldas, J. M., Almeida, M. C., \& Killaspy, H. (2011). Long-Term Mental Health Care for People with Severe Mental Disorders. İndirilme Tarihi 13 Ekim 2016, URL: https://ec.europa.eu/

Cameron, D., \& McGowan, P. (2013). The Mental Health Social Worker as a Transitional Participant: Actively Listening to 'Voices' and Getting into the Recovery Position. Journal of Social Work Practice, 27(1), 21-32.

Camkurt, M. Z. (2013). 2022 Sayılı Kanuna Göre Engelliliğin Tespiti ve Engelliliğe Dayalı Aylıkların Bağlanması İşlemleri. Mali Çözüm Dergisi, 119, 79-116.

Carpenter, J. (2002). Mental Health Recovery Paradigm: Implications for Social Work. Health Soc Work, 27(2), 86-94.

Chow, W. S., \& Priebe, S. (2013). Understanding Psychiatric Institutionalization: A Conceptual Review. BMC Psychiatry, 13, 169.

Çabalar, M., Tatlıdede, A. D., Yazar, T., Güveli, B. ve Yayla, V. (2011). Nörolojik Hastalıkların Özürlülük Derecelerinin Sağlık Kurulunda Değerlendirilmesi. Bakırköy Tıp Dergisi, 7, 142-146.

Çetin, M. (2005). Psikiyatrinin Kısa Tarihi. Araştırma ve Klinik Uygulamada Biyolojik Psikiyatri Şizofreni, 1. Ed: Emin Ceylan ve Mesut Çetin. 3. Baskı, İstanbul, Yerküre Yayıncılık, 167.

Çetin, M. ve Ceylan, E. (2005). Genel Bilgiler, Şizofrenin Tarihçesi. Araştırma ve Klinik Uygulamada Biyolojik Psikiyatri Şizofreni, 1. Ed: Emin Ceylan ve Mesut Çetin. 3. Baskı, İstanbul, Yerküre Yayıncılık, 83-123.

Danış, M. Z. ve Genç, Y. (2011). Kurumsal Bakım Elemanlarının Genel Özellikleri ve Yaşadıkları Sorunlar. Yalova Sosyal Bilimler Dergisi, 2, 170-183.

Daşbaş, S. (2014). 65 Yaş Üstü Bireylerin Aile İçi Yaşlı İstismarı Konusundaki Değerlendirmeleri. Doktora tezi, Hacettepe Üniversitesi, Ankara.

Devlet İstatistik Enstitüsü (DİE) (2004).Türkiye Engelliler Araştırması 2002. Ankara, Devlet İstatistik Enstitüsü. İndirilme Tarihi: 10 Nisan 2017 URL: www.tuik.gov.tr

Donovan, K., Regehr, C., \& George, M. (2013). Nursing Home Care for Adults with Chronic Schizophrenia. Sol Work Ment Health, 11(2), 167-188.

Duyan, V. (2010). Sosyal Hizmet Temelleri Yaklaşımları Müdahale Yöntemleri. Ankara, Aydınlar Matbaacilik, 1. Basim. 96-107.

Foucault, M. (2006). Deliliğin Tarihi. 4. Baskı, Ankara, İmge Kitabevi. 
Genç, Y. ve Barış, İ. (2015). Yaşlı Bakım Hizmetlerinde Çağdaş Yaklaşım: Kurumsal Bakım Yerine Evde Bakım Hizmetlerinin Güçlendirilmesi. Akad Sos Araşt Dergisi, 3(10), 3657.

Genç, Y. ve Barış, İ. (2015). Sosyal Hizmetlerin Yeniden Yapılandırılmasında Yerinden Yönetimin İşlevselliği. International Journal of Social Science, 32, 95-117.

Gilburt, H., Peck, E., Ashton, B., Edwards, N., \& Naylor, C. (2014). Service Transformation Lessons From Mental Health. İndirilme Tarihi: 15 Ekim 2017, URL: https://www.kingsfund.org.uk

Goffman, E. (1961). Asylums: Essays on the Social Situation of Mental Patients and Other Inmates. Anchor Books.

İnan, S., Peker, G. C., Tekiner, S., Ak, F. ve Dağlı, Z. (2013). Engellilik, Türkiye'de Engellilerin Durumu Ve Sağlık Hizmet Sunumuna Bir Bakış. Prev Med Bull, 12(6), 723-72.

Johnson, M. M., \& Rhodes, R. (2007). Institutionalization: A Theory of Human Behavior and the Social Environment. Advances in Social Work, 8(1), 219-236.

Köknel, Ö. (2000). Günlük Hayatta Ruh Sağhl̆ğı. İstanbul, Alfa Yayınları.

Lacey, D. (2005). Nursing Home Social Worker Skills and End-Of-Life Planning. Social Work in Health Care, 40(4), 19-40.

Leedahl, S. N., Chapin, R. K., Wendel, C., Baca, B. A., Hasche, L. K., \& Townley, G. W. (2015). Successful Strategies for Discharging Medicaid Nursing Home Residents with Mental Health Diagnoses to the Community. J Soc Serv Res, 41(2), 172-192.

Lehman, A. F., Slaughter, .J. G., \& Myers, P. M. (1991). Quality of Life Alternative Residential Settings. Psychiatric Quarterly, 62(1), 35-50.

Liberman, R. P. (2011). Yeti Yitiminden İyileşmeye: Psikiyatrik İyileştirim Elkitabı. Çeviri: Yıldız M. Türkiye Sosyal Psikiyatri Derneği, Ankara.

Mares, A. S., Young, A. S., McGuire, J. F., \& Rosenheck, R. A. (2002). Residential Environment and Quality of Life among Seriously Mentally Ill Residents of Board and Care Homes. Community Mental Health Journal, 38(6), 447-460.

Mavili Aktaş, A. (2004). Aile Terapisinde Sosyal Hizmet Yaklaşımı. Aile ve Toplum, 6(2).

Mechanic, D., \& McAlpine, D. D. (2000). Use of Nursing Homes in the Care of Persons with Severe Mental Illness: 1985 to 1995. Psychiatric services, 51(3), 354-358.

Oral, M. ve Tuncay, T. (2012). Ruh Sağlığı Alanında Sosyal Hizmet Uzmanlarının Rol ve Sorumlulukları. Toplum ve Sosyal Hizmet, 23(2), 93-114.

Özbaş, D. ve Buzlu, S. (2011). Geçmişten Günümüze Psikiyatri Hemşireliği. İ.Ü.F.N. Hem. Dergisi, 19( 3), 187-193.

Özdemir, U. (2000). Türkiye' de Psikiyatrik Sosyal Hizmet. Ankara, Aydınlar Matbaası.

Öztürk, O. (1997). Ruh Sağlı̆̆ı ve Bozuklukları. Ankara, Hekimler Yayın Birliği. 
Priebe, S., Badesconyi, A., Fioritti, A., Hansson, L., Kilian, R., Torres-Gonzales, F., Turner, T., \& Wiersma, D. (2005). Reinstitutionalisation in Mental Health Care: Comparison of Data on Service Provision from Six European Countries. BMJ, 330, 123-126.

Priebe, S., Habil, M., Frottier, P., Gaddini, A., Kilian, R., Lauber, C., Leal, R.M., Jørgensen, P. M., Walsh, D., Wiersma, D., \& Wright, D. (2008). Mental Health Care Institutions in Nine European Countries, 2002 to 2006. Psychiatric Services, 59(5), 570-574.

Rahman, M., Grabowski, D. C., Intrator, O., Cai, S., \& Mor, V. (2013). Serious Mental İllness and Nursing Home Quality of Care. Health Serv Res, 48(4). 1279-1298.

Raske, M. (2010). Nursing Home Quality Of Life: Study of an Enabling Garden. J Gerontological Social Work, 53(4), 336-351.

Reeves, W. C., Strine, T. W., Pratt, L. A., Thompson, W., Ahluwalia, I., Dhingra, S. S., McKnight-Eily, L. R., Harrison, L., D'Angelo, D. V., Williams, L., Morrow, B., Gould, D., \& Safran, M. A. (2011). Mental Illness Surveillance among Adults in the United States. 2, 2011 / 60, 03, 1-32, İndirilme Tarihi 14 Ekim 2017 URL: https://www.cdc.gov

Resmi Gazete, 24 Mayıs 1983. 2828 sayılı, "Sosyal Hizmetler Kanunu”.

Resmi Gazete, 01 Temmuz 2005. 5378 sayılı, “Engelliler hakkında Kanun”.

Resmi Gazete, 30 Temmuz 2006. 26244 sayılı, “ Bakıma Muhtaç Özürlülerin Tespiti ve Bakım Hizmeti Esaslarının Belirlenmesine İlişkin Yönetmelik".

Resmi Gazete, 30 Temmuz 2006. 26244 sayılı, “ Bakıma Muhtaç Özürlülere Yönelik Özel Bakım Merkezleri Yönetmeliği".

Resmi Gazete, 03 Eylül 2010. 27691 sayılı “Engellilerin Bakımı, Rehabilitasyonu ve Aile Danışmanlığ1 Hizmetlerine Dair Yönetmelik".

Resmi Gazete, 30 Mart 2013. 28603 sayılı, “Özürlülük Ölçütü, Sınıflandırması Ve Özürlülere Verilecek Sağlık Kurulu Raporları Hakkında Yönetmelik".

Resmi Gazete, 04 Kasım 2016. 29878 sayılı, “Bakıma Muhtaç Engellilere Yönelik Özel Bakım Merkezleri Yönetmeliği".

Salter, M., \& Turner, T. (2008). Community Mental Health Care: A Practical Guide to Outdoor Psychiatry. Elsevier Health Sciences. 1. Basim.

Saruç, S. ve Kaya Kılıç, A. (2015). Toplum Ruh Sağlı̆̆ı Merkezi'nden Hizmet Alan Hastaların Sosyal Profili ve Merkezde Verilen Hizmetler. Toplum ve Sosyal Hizmet, 26(2), 53-71.

Shadish, W. R., \& Bootzin, R. R. (1981). Nursing Homes and Chronic Mental Patients. Schizophrenia Bulletin, 7(3), 488-498.

Solanki, R. K., Singh, P., Midha, A., \& Chugh, K. (2008). Schizophrenia: Impact on Quality Of Life. Indian J Psychiatry, 50(3), 181-186.

Soygür, H. (2000). Bakımevlerinde Yaşlı Bakımı ve Psikolojik Değerlendirme. Demans Dizisi, $1,32-40$.

Street, D., Molinari, V., \& Cohen, D. (2013). State Regulations for Nursing Home Residents with Serious Mental Illness. Community Ment Health J, 49, 389-395. 
Şişman, Y. (2011). Türkiye'de Özürlülere Yönelik Yasal Düzenlemeler. Sosyal Siyaset Konferanslar1, 60(1), 169-221.

Taylor, T. L., Killaspy, H., Wright, C., Turton, P., White, S., Kallert, T. M., Schuster, M., Cervilla, J. A., Brangier, P., Raboch, J., Kališová, L., Onchev, G., Dimitrov, H., Mezzina, R., Wolf, K., Wiersma, D., Visser, E., Kiejna, A., Piotrowski, P., Ploumpidis, D., Gonidakis, F., Caldas-de-Almeida, J., Cardoso, G., \& King, M. B. (2009). A Systematic Review of the International Published Literature Relating To Quality of Institutional Care for People with Longer Term Mental Health Problems. BMC Psychiatry, 9, 55.

T.C. Başbakanlık Aile ve Sosyal Politikalar Bakanlığı, Yaşlı ve Engelli Hizmetleri Genel Müdürlüğü, İndirilme Tarihi 01Eylül 2015, URL: http://eyh.aile.gov.tr/

Thornicroft, G., \& Tansella, M. (2003). What Are The Arguments For Community-Based Mental Health Care? WHO regional Office for Europe's health evidence network.

Turan, N. (1999). Sosyal Kişisel Çalışma. Birey ve Aile için Sosyal Hizmet. Aydınlar, Ankara.

Turkçapar, H. ve Göka, E. (1995). Psikiyatrinin İşlevi. Kriz Dergisi, 3,(1,2), 179-181.

Türkiye İstatistik Kurumu, 2010. Engellilerin Sorun ve Beklentileri Araştırması. Ankara. İndirilme Tarihi: 10 Nisan 2017, URL: www.tuik.gov.tr

Ulaş, S. C. ve Uçku, R. (2012). Türkiye' de Özürlülük ve Özürlülere Sunulan Hizmetler. TAF Prev Med Bull,11(4), 483-488.

Vongxarburana, E., Thomas, K. S., Frahm, K. A., \& Hyer, K. (2011). The Social Worker in Interdisciplinary Care Planning. Clinical Gerontologist, 34(5), 367-378.

Yanık, M. (2007). Türkiye Ruh Sağlığı Sistemi Üzerine Değerlendirme ve Öneriler Ruh Sağlığı Eylem Planı Önerisi. RCHP, Psikiyatride Derlemeler, Olgular ve Varsayımlar Dergisi Özel sayı.

Yıldız, M. (2009). Psikiyatrik Rehabilitasyon. Kocaeli Üniversitesi Tıp Fak Psikiyatri AD. Bireyden Topluma Ruh Sağlığı. Ed: Işık Sayıl, İstanbul, Erler Matbaacılık, 151- 161.

Yohanna, D. (2013). Virtual Mentor. American Medical Association Journal of Ethics, 15(10), 886891.

Yüksel, N. (2001). Ruhsal Hastalıklar. 2. Baskı, Ankara, Çizgi Tıp Yayınevi.

Zastrow, C. (2014). Sosyal Hizmete Giriş. Ed: Baran Çiftçi D, 2. Basım, Ankara, Nika.

Wakefield, J. C. (2013). Dsm-5 and Clinical Social Work: Mental Disorder and Psychological Justice as Goals of Clinical Intervention. Clin Soc Work J, 41, 131-138.

World Health Organization; 2011. World report on disability. 9. İndirilme Tarihi 19 Nisan 2017 URL: http://www.who.int/topics/disabilities/en/ 